\title{
Biosorption characteristics of methylene blue dye by two fungal biomasses
}

Hadj Daoud Bouras ${ }^{\mathrm{a}, \mathrm{b}, *}$, Zelal Isik ${ }^{\mathrm{c}}$, Ezgi Bezirhan Arikan ${ }^{\mathrm{c}}$, Ahmed Réda Yeddou $^{\mathrm{a}}$, Noureddine Bouras ${ }^{\mathrm{d}, \mathrm{e}}$, Abdelmalek Chergui ${ }^{\mathrm{a}}$, Lidia Favier ${ }^{\mathrm{f}}$, Abdeltif Amrane $^{\mathrm{f}}$, Nadir Dizge ${ }^{\mathrm{c}}$

${ }^{a}$ Laboratoire d'Etude et de Développement des Techniques de Traitement et d'Epuration des Eaux et de Gestion Environnementale (LEDTEGE), Ecole Normale Supérieure de Kouba, BP 92, 16308, Vieux-Kouba, Alger, Algeria

${ }^{b}$ Département de Physique, Ecole Normale Supérieure de Laghouat, BP 4033, RP Rue des martyrs, Laghouat, Algeria

${ }^{c}$ Department of Environmental Engineering, Mersin University, Mersin, 33343, Turkey

${ }^{d}$ Laboratoire de Biologie des Systèmes Microbiens (LBSM), Ecole Normale Supérieure de Kouba, BP 92, 16308, Vieux-Kouba, Alger, Algeria

${ }^{e}$ Département de Biologie, Faculté des Sciences de la Nature et de la Vie et Sciences de la Terre, Université de Ghardaïa, BP 455, Ghardaïa 47000, Algeria

${ }^{f}$ Univ-Rennes, Ecole Nationale Supérieure de Chimie de Rennes, CNRS, ISCR - UMR6226, Rennes,

France

${ }^{*}$ Corresponding author. Tel.: +213550233576

E-mail address: hadjdaoud_bouras@yahoo.fr (Hadj Daoud Bouras). 


\section{Abstract}

A novel approach has been tried to use both Aspergillus carbonarius (AC) and Penicillium glabrum (PG) fungi for the first time to remove methylene blue (MB) from aqueous solutions. The biosorption was favoured using a biosorbent concentration of $0.33 \mathrm{~g} / \mathrm{L}$ at $\mathrm{pH}$ 8.2. Biosorption kinetics were evaluated for different dye concentrations (5-25 mg/L). The resulting biosorbent was characterised by scanning electron microscopy (SEM), X-ray diffractometer and Fourier transformer infrared spectroscopy (FTIR) techniques. The maximum biosorption capacities of AC and PG for MB were $21.88 \mathrm{mg} / \mathrm{g}$ and $16.67 \mathrm{mg} / \mathrm{g}$, respectively at $30{ }^{\circ} \mathrm{C}$. The results suggested that $A$. carbonarius and P. glabrum could be used as biosorbents for the effective removal of methylene blue from dye wastewater in terms of biosorption capacity, availability and low cost.

Keywords: Fungal biomass; methylene blue; biosorption; isotherms. 


\section{Introduction}

Synthetic dyes, an important group of chemicals, are also pollutants. They are discharged during the production of textiles, cosmetics, paper, pharmaceuticals, volatile organic compounds, and leather, in a spectrum of colours [1]. There are more than 100,000 commercial dyes worldwide, amounting to approximately $7 \times 10^{8}-1 \times 10^{9} \mathrm{~kg}$ per year [2]. It is estimated that about 10 to $15 \%$ of the dyes used in the production processes are lost in the effluent [3], and the average dye concentration detected in the effluents is $300 \mathrm{mg} / \mathrm{L} \mathrm{[4].} \mathrm{Most}$ of the dyes are considered to be recalcitrant to the natural degradation processes such as heat, photodegradation and biodegradation because of their complex molecular structures [5]. Various physicochemical approaches have been used for the elimination of dyes such as adsorption, precipitation, photo-oxidation, coagulation, flocculation, reduction, and electrochemical treatment [6].

Biosorption is considered an attractive alternative for treating wastewater contaminated with dyes [7]. Current research focuses on microbial biomass, because it is an environmentfriendly approach that can be used to remove azo dyes contaminants [8]. Fungal biomass holds distinct advantages over other microorganisms with respect to industrial exploitation. It is available on a large scale, it can grow in a cheap medium, and it can be easily harvested [9]. Besides, the composition of fungal cell walls (chitin, glucan, mannan, proteins, amino and hydroxyl groups) makes their biomasses suitable for biosorption [10]. Fungal species such as Trichoderma asperellum [11], Aspergillus fumigatus [12], Trametes versicolor [13], Fusarium solani [14], Coriolopsis sp. and Penicillium simplicissimum [15, 16] have been reported as efficient dye-decolourizers. Methylene blue (MB) is a thiazine cationic dye. It is considered a common pollutant in textile wastewater and is often used in dye houses and textile industries [17]. Both Aspergillus carbonarius (AC) and Penicillium glabrum (PG) have been proven to be very efficient in biosorption of Congo red [18]. 
In the present study these biomaterials were investigated for their capability to remove MB. For this purpose, the main factors affecting decolorisation such as contact time, initial $\mathrm{pH}$, biosorbent concentration, and dye concentration were examined. Biosorption equilibrium data were analysed by Langmuir, Freundlich, Temkin and Dubinin-Radushkevich isotherm models. The biosorption kinetic data of the biomass were tested by the pseudo-first-order, the pseudo-second-order kinetic and intraparticle diffusion models. In order to reveal the adsorption characteristic of AC and PG biomasses, Scanning electron microscopy (SEM) and Fourier Transform Infrared Spectroscopy (FTIR) spectra analyses were carried out.

\section{Materials and methods}

\section{Preparation of the biosorbents}

Both micro-fungi Aspergillus carbonarius (AC) and Penicillium glabrum (PG) were obtained from the fungal collection of the Laboratoire de Génie Chimique, Université de Toulouse (France). They were cultivated on Potato Dextrose Agar (PDA) medium in Petri dishes at room temperature $\left(25 \pm 1^{\circ} \mathrm{C}\right)$. The fungal mycelium was cultured in liquid Sabouraud medium (1L): (10 g sucrose and 7 g peptone) under $25^{\circ} \mathrm{C}$ for 19 days of incubation (without shaking). Collected mycelia were washed by distilled water and dried for $24 \mathrm{~h}$ at $80{ }^{\circ} \mathrm{C}$. The dried biomass was crushed and sieved to $500 \mu \mathrm{m}$ particle size using the ASTM standard test sieves (No: 35) to obtain AC and PG biosorbents [19].

\section{Dye solution preparation}

Methylene blue (MB) was chosen as a representative of cationic dye group. MB was supplied by Fluka (chemical formula: $\mathrm{C}_{16} \mathrm{H}_{18} \mathrm{ClN}_{3} \mathrm{~S}$; molecular weight $319.86 \mathrm{~g} / \mathrm{mol}$; maximum wavelength $663 \mathrm{~nm}$ ). Figure 1 shows the chemical structure of the dye. A stock solution of $100 \mathrm{mg} / \mathrm{L}$ was prepared in ultrapure water. The required concentrations ranging from 10 to 50 $\mathrm{mg} / \mathrm{L}$ were prepared by diluting the stock solution.

\section{Characterisation of the biosorbents}


The selected biosorbents were characterised using Fourier transform infrared spectrophotometer in the region of $400-4000 \mathrm{~cm}^{-1}$ (FTIR, Perkin-Elmer Spectrum 400). The pattern of X-ray diffraction of the biosorbents; AC and PG was analysed using XRD, Rigaku Dmax-Rapid II. The morphology was visualised using scanning electron microscopy (SEM, Zeiss Supra 55). The images were taken by applying electron beam with an acceleration voltage of $10.0 \mathrm{kV}$.

\section{Biosorption experimental procedure}

The selected biosorbents underwent a series of batch experiments to study the effect of several parameters such as pH (2-11), initial dye concentration (5-25 mg/L), contact time (0$180 \mathrm{~min})$, and temperature $\left(25,30\right.$ and $\left.35^{\circ} \mathrm{C}\right)$ at $\mathrm{pH}$ 8.2. Biosorption experiments were conducted using $10 \mathrm{mg} / \mathrm{L}$ dye solutions and $0.33 \mathrm{~g} / \mathrm{L}$ of biosorbent in $30 \mathrm{~mL}$ solution volume. Mixtures were shaken at $30{ }^{\circ} \mathrm{C}$ and $250 \mathrm{rpm}$ on a rotary shaker (New Brunswick Scientific Company, New Jersey, USA) to reach equilibrium. After the sorption process, the biosorbent was centrifuged and separated from the dye solution by Microlitre Centrifuges, Heraeus instruments, Biofuge at $16,000 \mathrm{~g}(12,000 \mathrm{rpm})$ for $10 \mathrm{~min}$. Then, the remaining dye concentrations in the supernatants were analysed by a UV-vis spectrophotometer (JENWAY UV-vis 6705) at $663 \mathrm{~nm}$. The adsorption equilibrium $\mathrm{q}_{\mathrm{e}}(\mathrm{mg} / \mathrm{g})$ at different solute concentrations of MB adsorbed by AC and PG was calculated according to equation (1).

$$
q_{e}=\frac{\left(c_{0}-C_{e}\right) V}{m}
$$

Where $\mathrm{C}_{0}$ and $\mathrm{C}_{\mathrm{e}}$ are the initial and equilibrium concentrations of methylene blue, respectively (mg/L). $\mathrm{V}$ is the volume of MB solution $(\mathrm{L})$ and $\mathrm{m}$ is the mass of adsorbent used (g). The percent removal of dyes from aqueous solution was calculated using equation (2).

$$
R \%=\frac{\left(c_{0}-c_{e}\right)}{c_{0}} \times 100
$$

\section{Nonlinear regression analysis}


All kinetic and isotherm parameters of the models were evaluated by non-linear regression analysis of the experimental data. The correlation coefficients $\left(\mathrm{R}^{2}\right)$ and the root mean squared error or standard error (RMSE) of the estimate were used as a measure of the goodness-of-fit of the mathematical models. Values of $\mathrm{R}^{2}$ close to 1.0 and small RMSE values indicate better curve fitting.

$$
\text { RMSE }=\sqrt{\frac{1}{n-2} \sum_{1}^{n}\left(q_{i}-q_{i e}\right)^{2}}
$$

Where, $\mathrm{q}_{\mathrm{i}}(\mathrm{mg} / \mathrm{g})$ is the experimental value of uptake, $\mathrm{q}_{\mathrm{ie}}$ is the calculated value of uptake using a model (mg/g), and $\mathrm{n}$ is the number of observations in the experiment.

\section{Results and discussion}

\section{Characterisation of A. carbonarius and P. glabrum surfaces}

In order to check the structure of AC and PG, an XRD study was performed, as shown in Figure 2(a,b), respectively. The XRD patterns did not show any crystalline phase of the material, only a pronounced wide band at $2 \theta$ in the range of $10^{\circ}$ to $30^{\circ}$ was observed, indicating an amorphous structure [20]. The SEM images characterising the surface morphology of AC and PG are illustrated in Figure 3(a,b), respectively. Through these images, it can be observed that AC and PG showed an irregular surface structure, with different particle sizes, characterising a rough texture. These characteristics are beneficial for easy and quick mass penetration during adsorption [21]. These properties allow more interaction of the dye with the biosorbent structure [22]. FTIR analysis was performed to characterise the functional groups that were responsible for the biosorption process. Figure 4 (a,b), respectively show the spectrum of FTIR captured before and after MB dye biosorption onto A. carbonarius and P. glabrum. Table 1 shows the changes in the FTIR functional group bands, along with the band positions, before and after dye loading. 
The major bands found in the AC biomass before biosorption were close to 3269, 2924, 2121, 1620, $1023 \mathrm{~cm}^{-1}$. In the FTIR of AC before biosorption, the broad band with a vibrational elongation around $3269 \mathrm{~cm}^{-1}$ indicates the presence of the hydroxyl $(\mathrm{OH})$ and amino $(\mathrm{NH})$ groups on the surface of AC [23]. The peak at $2926 \mathrm{~cm}^{-1}$ indicates the $\mathrm{C}-\mathrm{H}$ stretch vibration asymmetric [24]. The band at $1023.18 \mathrm{~cm}^{-1}$ is assigned to the $\mathrm{C}-\mathrm{O}$ stretching vibration while the large bands at $1620.63 \mathrm{~cm}^{-1}$ could be attributed to $\mathrm{C}=\mathrm{C}$ bonds. The band at $1620.63 \mathrm{~cm}^{-1}$ is assigned to $\mathrm{C}=\mathrm{C}$ and $\mathrm{C}=\mathrm{O}$ stretching in the aromatic ring. Slight horizontal shifts were detected after $\mathrm{MB}$ adsorption indicating that $-\mathrm{OH},-\mathrm{COOH}$, and $-\mathrm{NH}$ groups on the surface of A. carbanarius were responsible for the biosorption process through complexation mechanism.

Figure 4(b) shows the FTIR results of the P. glabrum fungal biomass before and after biosorption of methylene blue. The $-\mathrm{NH}$ absorption peak is shifted from $3271.0 \mathrm{~cm}^{-1}$ to $3272.0 \mathrm{~cm}^{-1}$ upon adsorption of MB. The peak at 2923 and $2854 \mathrm{~cm}^{-1}$ is indicative of stretching of $\mathrm{C}-\mathrm{H}$ bond of methyl and methylene groups [25]. The peaks located around 1740 $\mathrm{cm}^{-1}$ are characteristic to carbonyl group stretching vibrations [26].The amide I band is mainly a $\mathrm{C}=\mathrm{O}$ stretching mode and is centred at $1643 \mathrm{~cm}^{-1}$; the amide II band is a combination of $\mathrm{N}-\mathrm{H}$ bending and $\mathrm{C}-\mathrm{N}$ stretching, being centred near $1539 \mathrm{~cm}^{-1}$; the $\mathrm{C}-\mathrm{N}$ stretching of amide III band is located near1228 $\mathrm{cm}^{-1}$ [27]. The shifting of the band from 1042.9 to $1027.1 \mathrm{~cm}^{-1}$ also suggests the activity of $\mathrm{C}-\mathrm{O}$ group in $\mathrm{MB}$ binding, and the peak observed at $698 \mathrm{~cm}^{-1}$ corresponds to the $\mathrm{N}-\mathrm{H}$ out-of-plane bending.

\section{Effect of pH}

The $\mathrm{pH}$ of the biosorption medium is an important parameter affecting the biosorbent uptake of dye from aqueous solutions. Therefore, MB dye biosorption onto AC and PG was investigated using $0.33 \mathrm{~g} / \mathrm{L}$ of biosorbent, with initial dye concentration of $10 \mathrm{mg} / \mathrm{L}$, varying the $\mathrm{pH}$ from 3 to 11 . Figure 5 shows the results, indicating a maximum biosorption capacity 
of $21.60 \mathrm{mg} / \mathrm{g}$ and $24.53 \mathrm{mg} / \mathrm{g}$ for AC and PG at $\mathrm{pH}$ 11, respectively. This suggests that MB biosorption onto both fungi is favourable in neutral to alkaline conditions. At these favourable conditions, there is electrostatic force of attraction between the cationic dye and the surface charge of the biosorbents, which became negatively charged at $\mathrm{pH}>5.76$ and 6.40 , for $\mathrm{AC}$ and PG, respectively. At the low pH values, the dye removal by biosorbent was low because the acidic condition produces more $\mathrm{H}^{+}$ions in the aqueous solution. Similar results were reported in the cationic dye adsorption onto Arundo donax activated carbon [28].

\section{Effect of the biosorbent concentration}

Figure 6(a,b), respectively show the effect of the biosorbent concentration on the uptake of methylene blue on A. carbonarius and P. glabrum fungi. Removal of MB increased from $48.21 \%$ to $70.36 \%$ and from $41.37 \%$ to $71.66 \%$ for AC and PG respectively, when the concentration was increased from 0.33 to $0.67 \mathrm{~g} / \mathrm{L}$. This can be attributed to the increasing surface area of the adsorbent as well as the availability of more adsorption sites [29]. In contrast, the biosorption capacity decreased from 14.56 to $3.25 \mathrm{mg} / \mathrm{g}$ and 17.49 to $3.49 \mathrm{mg} / \mathrm{g}$ for AC and PG, respectively. This decrease in biosorption capacity of the dye with increasing biosorbent concentration can be attributed to a greater number of sites that remain unsaturated during the biosorption reaction, as well as the agglomeration of biosorbent particles [30].

\section{Effect of the contact time}

Figure 7 shows the effect of the contact time $(0-180 \mathrm{~min})$ on the biosorption of $\mathrm{MB}$ onto the two biosorbents. For both A. carbonarius and P. glubrum fungal biomass, at an initial dye concentration of $10 \mathrm{mg} / \mathrm{L}$, the biosorption rate was rapid in the first $40 \mathrm{~min}$, then its rate became slow leading to a single, smooth and continuous saturation curve. At equilibrium, MB removal for AC was $20.32 \mathrm{mg} / \mathrm{g}$ compared to $12.80 \mathrm{mg} / \mathrm{g}$ for PG.

\section{Effect of the initial dye concentration}


The biosorption process is greatly influenced by the initial concentration of the adsorbate. Figure 8 shows the effect of the initial dye concentration on the biosorption capacity of AC and PG biosorbents. By increasing the initial dye concentration, the biosorption capacity was found to increase from 11.16 to $20.02 \mathrm{mg} / \mathrm{g}$ for AC and from 10.76 to $15.91 \mathrm{mg} / \mathrm{g}$ for PG; and the removal yield was found to decrease from 74.59 to $26.38 \%$ and from 71.33 to $21.82 \%$ for AC and PG, respectively. A similar trend was observed with biosorption of methylene blue onto Carica papaya wood and Aspergillus fumigatus [2, 12]. This trend might be caused by the increase in the necessary driving force to overcome the resistance to the mass transfer of all molecules between the aqueous phase and the biosorbents [31].

\section{Biosorption kinetics}

The pseudo-first-order Lagergen, the pseudo-second-order and the intraparticle diffusion models were tested to describe the biosorption kinetics.

The linear form of the pseudo-first-order rate equation [18] is given as:

$$
\ln \left(q_{e}-q_{t}\right)=\ln q_{e}-\frac{k_{1}}{2.303} t
$$

Where $\mathrm{q}_{\mathrm{e}}$ and $\mathrm{q}_{\mathrm{t}}$ are the amounts of the MB dye sorbed at equilibrium time (mg/g) and $\mathrm{t}(\mathrm{min})$, respectively, and $\mathrm{k}_{1}$ is the first-order rate constant $\left(\mathrm{min}^{-1}\right)$.

The pseudo-second-order rate equation [32] is given as:

$$
\frac{t}{q_{t}}=\frac{1}{k_{2} q_{2}^{2}}+\frac{1}{q_{2}} t
$$

Where $\mathrm{k}_{2}$ (mg/g min) is the second-order rate constant, $\mathrm{q}_{\mathrm{t}}(\mathrm{mg} / \mathrm{g})$ is the amount of biosorption after time $\mathrm{t}(\mathrm{min})$ and $\mathrm{q}_{\mathrm{e}}$ is the amount of biosorption equilibrium (mg/g). The intraparticle diffusion equation [33] is expressed as:

$$
q_{t}=k_{i d} t^{1 / 2}+C_{i}
$$


Where $\mathrm{q}_{\mathrm{t}}(\mathrm{mg} / \mathrm{g})$ is the amount adsorbed at time $\mathrm{t}(\mathrm{min}), \mathrm{k}_{\mathrm{id}}\left(\mathrm{mg} / \mathrm{g} \mathrm{min}^{1 / 2}\right)$ is the rate constant of intraparticle diffusion. $\mathrm{C}_{\mathrm{i}}(\mathrm{mg} / \mathrm{g})$ is a constant that gives an idea about the thickness of the boundary layer.

Elovich model [34] is suitable for systems with heterogeneous biosorbing surfaces and can be written as:

$$
q_{t}=\frac{1}{\beta} \ln (\alpha \beta)+\frac{1}{\beta} \ln t
$$

The kinetic parameters for methylene blue biosorption onto AC and PG are shown in Table 2. The values of $R^{2}$ and RMSE from the table revealed that the pseudo-second-order was better for describing the biosorption process. Thus, the estimated biosorption capacity of biosorbent for MB by the pseudo-second-order model was very close to the experimental values. The straight lines did not go through the origin, indicating that the pore diffusion was not the only rate-controlling step (figure not shown). This indicated that the biosorption process might be of complex mechanism including both surface biosorption and intraparticle diffusion [20].

\section{Biosorption isotherm}

The present results obtained from batch experiment were analysed by using the most common isotherms; Langmuir, Freundlich, Temkin and Dubinin-Radushkevich adsorption isotherm models. The linear form of the Langmuir model [35] is given as:

$$
\frac{c_{e}}{q_{e}}=\frac{1}{b q_{m}}+\frac{c_{e}}{q_{m}}
$$

Where $\mathrm{q}_{\mathrm{e}}$ is the amount adsorbed at equilibrium $(\mathrm{mg} / \mathrm{g})$ and $\mathrm{C}_{\mathrm{e}}$ is the equilibrium concentration of the adsorbate (mg/L). The Langmuir constants $\mathrm{q}_{\mathrm{m}}(\mathrm{mg} / \mathrm{g})$ represent the monolayer biosorption capacity and b $(\mathrm{L} / \mathrm{mg})$ relates to the heat of biosorption. A plot of $\mathrm{C}_{\mathrm{e}} / \mathrm{q}_{\mathrm{e}}$ versus $C_{e}$ gives a straight line of slope $1 / q_{m}$ and intercepts $1 / q_{m} b$ is shown in Figure 9 . The 
most important characteristics of the Langmuir isotherm can be expressed in terms of a dimensionless separation factor $\left(\mathrm{R}_{\mathrm{L}}\right)$ which is defined according to Dahlan et al. [36].

$$
\mathrm{R}_{\mathrm{L}}=\frac{1}{1+b C_{0}}
$$

$R_{L}$ values indicate whether the adsorption process is irreversible $\left(R_{L}=0\right)$, favourable $\left(0<R_{L}<\right.$ 1), linear $\left(R_{L}=1\right)$, or unfavourable $\left(R_{L}>1\right)$. As the value of $R_{L}$ in our study is less than1 and greater than 0 , this indicates the favourable uptake of methylene blue compounds by both Aspergillus carbonarius and Penicillium glabrum biomasses.

The Freundlich isotherm assumes a heterogeneous surface with a non-uniform distribution of biosorption heat over the surface, which is expressed in the following equation [37]:

$$
\ln q_{e}=\ln K_{f}+\left(\frac{1}{n}\right) \ln C_{e}
$$

Where $\mathrm{K}_{\mathrm{F}}\left(\mathrm{mg} / \mathrm{g}(\mathrm{L} / \mathrm{mg})^{1 / \mathrm{n}}\right)$, defined as the adsorption or distribution coefficient, is related to the adsorption capacity; $\mathrm{n}$ is a measure of the adsorption intensity and gives indication on the favourability of the adsorption. Figure 10 shows the linear plot of specific adsorption ( $\mathrm{Ln} \mathrm{q}_{\mathrm{e}}$ ) against the ( $\left.\operatorname{Ln} C_{e}\right)$ for Freundlich model.

The Temkin isotherm assumes that (i) the heat of adsorption of all the molecules in the layer decreases linearly with coverage owing to adsorbent-adsorbate interactions, and (ii) adsorption is characterised by a uniform distribution of binding energies, up to some maximum binding energy, which is expressed in the following equation [38]:

$$
q_{e}=\frac{R T}{b_{T}} \ln C_{e}+\frac{R T}{b_{T}} \ln K_{T}
$$

Where $\mathrm{K}_{\mathrm{T}}(\mathrm{L} / \mathrm{g})$ and $\mathrm{b}_{\mathrm{T}}(\mathrm{kJ} / \mathrm{mol})$ are the Temkin constants. $\mathrm{K}_{\mathrm{T}}$ and $\mathrm{b}_{\mathrm{T}}$ constants were determined from the slope and intercepts of the plots obtained by plotting plot of qe versus Ln $\mathrm{C}_{\mathrm{e}}$. 
The D-R (Dubinin-Radushkevich) isotherm equation used to distinguish physical and chemical adsorption is described by equation [39]:

$$
\ln q_{\theta}=K \varepsilon^{2}+\ln q_{D R}
$$

Polanyi potential $(\varepsilon)$ is given as equation:

$$
\varepsilon=R T \ln \left(1+1 / C_{e}\right)
$$

Where $\mathrm{q}_{\mathrm{DR}}$ is the Dubinin-Radushkevich maximum adsorption capacity of dye (mg/g), $\mathrm{K}$ is the Dubinin-Radushkevich constant $\left(\mathrm{mol}^{2} / \mathrm{kJ}^{2}\right)$, $\mathrm{R}$ is the universal gas constant $(8.314 \mathrm{~J} / \mathrm{mol}$. $\mathrm{K})$ and $\mathrm{T}$ is the absolute temperature $(\mathrm{K})$. The plot of $\mathrm{Ln} \mathrm{q}_{\mathrm{e}}$ versus $\varepsilon^{2}$ gives a straight line with a slope of $\mathrm{K}$ and an intercept of lnqDR. The Dubinin-Radushkevich constant can give valuable information regarding the mean energy of adsorption by the following equation:

$$
\mathrm{E}=(-2 \mathrm{~K})^{-1 / 2}
$$

The adsorption isotherm parameters calculated for biosorption of MB by both Aspergillus carbonarius and Penicillium glabrum are presented in Table 3. The Langmuir isotherm model gave the most accurate description of $\mathrm{MB}$ sorption by the considered fungal strains. According to the Langmuir isotherm model, the maximum sorption capacities were 21.88 and $16.67 \mathrm{mg} / \mathrm{g}$ for A. carbonarius and P. glabrum, respectively. The equilibrium parameter or separation factor $\left(R_{\mathrm{L}}\right)$ obtained from Langmuir model indicated favourable dye biosorption of MB onto AC and PG. From Freundlich isotherm, the value of $n_{\mathrm{F}}$ constant, falling in the range of 1-10 also showed a suitable biosorption process [40]; whereas the values of $K_{T}$ and $b_{T}$ determined from Temkin for AC and PG model were 0.018, $0.163 \mathrm{~L} / \mathrm{g}$ and 0.722 and 0.331 $\mathrm{kJ} / \mathrm{mole}$, respectively. The (D-R) isotherm parameter; mean free energy (E) provides information about the biosorption mechanism as chemical ion exchange or physical adsorption. The values of the calculated mean energy (E) for both fungi AC and PG were less 
than $8 \mathrm{~kJ} / \mathrm{mol}$, indicating that the biosorption process of the dye was probably physically controlled [41]. Table 4 shows a comparison of the maximum adsorption capacity with those of some other adsorbents reported in literature. Both AC and PG biomasses showed relatively better biosorption potential of MB dye. The availability and cost effectiveness of Aspergillus carbonarius and Penicillium glabrum might provide a cheap source of biosorbents for the sequestration of toxic dyes from industrial effluents.

\section{Conclusions}

Both Aspergillus carbonarius and Penicillium glabrum biomasses were used for the removal of methylene blue (MB) from aqueous solutions. The adsorption equilibrium is consistent with Langmuir's model, and the adsorption kinetics fit the pseudo-second-order equation, indicating that the adsorption is controlled by interaction rather than diffusion. The maximum biosorption capacities of methylene blue onto A. carbonarius and P. glabrum were $21.88 \mathrm{mg} / \mathrm{g}$ and $16.67 \mathrm{mg} / \mathrm{g}$, respectively, at optimum conditions of $\mathrm{pH}(8.2)$ and temperature equals $30^{\circ} \mathrm{C}$. The biosorption equilibrium was reached in $120 \mathrm{~min}$. These results suggested that the biomaterials A. carbonarius and P. glabrum can be used as environmentally feasible and low cost biosorbents for the removal of methylene blue from aqueous solutions.

\section{Disclosure Statement}

No potential conflict of interest was reported by the authors.

\section{References}

[1] Bharti, V., Vikrant, K., Goswami, M., Tiwari, H., Sonwani, R.K., Lee, J., Tsang, D.C.W., Kim, K.-H., Saeed, M., Kumar, S., Rai, B.N., Giri, R.S., and Singh, B.S., 2019, Biodegradation of methylene blue dye in a batch and continuous mode using biochar as packing media. Environmental Research 171, 356-364. doi:10.1016/j.envres.2019.01.051 [2] Rangabhashiyam, S., Sujata, L., and Balasubramanian, P., 2018, Biosorption characteristics of methylene blue and malachite green from simulated wastewater onto Carica 
papaya wood biosorbent. Surfaces and Interfaces 10, 197-215. doi:10.1016/j. surfin.2017.09.011

[3] Mahmoud, M.S., Mostafa, M.K., Mohamed, S.A., Sobhy, N.A., and Nasr, M., 2017, Bioremediation of red azo dye from aqueous solutions by Aspergillus niger strain isolated from textile wastewater. Journal of Environmental Chemical Engineering 5(1), 547-554. doi:10.1016/j.jece.2016.12.030

[4] Mokhtar, N., Aziz, E.A., Aris, A., Ishak, W.F.W., and Ali, N.S.M., 2017, Biosorption of azo-dye using marine macro-alga of Euchema Spinosum. Journal of Environmental Chemical Engineering 5, 5721-5731. doi:10.1016/j.jece.2017.10.043

[5] Abdallah, R. and Taha, S., 2012, Biosorption of methylene blue from aqueous solution by nonviable Aspergillus fumigatus. Chemical Engineering Journal 195-196, 69-76. doi:10.1016/j.cej.2012.04.066

[6] Isik, Z., Arikan, E.B., Bouras, H.D., and Dizge, N., 2019, Bioactive ultrafiltration membrane manufactured from Aspergillus carbonarius M333 filamentous fungi for treatment of real textile wastewater. Bioresource Technology Reports 5, 212-219. doi:10.1016/j.biteb.2019.01.020

[7] Daneshvar, E., Vazirzadeh, A., and Bhatnagar, A., 2019, Biosorption of methylene blue dye onto three different marine macroalgae: Effects of different parameters on isotherm, kinetic and thermodynamic. Iranian Journal of Science and Technology, Transactions A: Science 43, 2743-2754. doi:10.1007/s40995-019-00764-8

[8] Arunarani, A., Chandran, P., Ranganathan, B.V., Vasanthi, N.S., and Khan, S.S., 2013, Bioremoval of basic violet 3 and acid blue 93 by Pseudomonas putida and its adsorption isotherms and kinetics. Colloids and Surfaces B: Biointerfaces 102, 379-384. doi:10.1016/j. colsurfb.2012.08.049

[9] Contreras, M., Grande-Tovar, C.D., Vallejo, W., and Chaves-López, C., 2019, Bio- 
removal of methylene blue from aqueous solution by Galactomyces geotrichum KL20A. Water 11(2), 282. doi:10.3390/w11020282

[10] Tonato, D., Drumm, F.C., Grassi, P., Georgin, J., Gerhardt, A.E., Dotto, G.L., and Mazutti, M.A., 2019, Residual biomass of Nigrospora sp. from process of the microbial oil extraction for the biosorption of procion red H-E7B dye. Journal of Water Process Engineering 31, 100818. doi:10.1016/j.jwpe.2019.100818

[11] Marcharchand, S. and Ting, A.S.Y., 2017, Trichoderma asperellum cultured in reduced concentrations of synthetic medium retained dye decolourization efficacy. Journal of Environmental Management 203, 542-549. doi:10.1016/j.jenvman.2017.06.068

[12] Kabbout, R. and Taha, S., 2014, Biodecolorization of textile dye effluent by biosorption on fungal biomass materials. Physics Procedia 55, 437-444. doi:10.1016/j. phpro.2014.07.063

[13] Casas, N., Parella, T., Vincent, T., Caminal, G., and Sarra, M., 2014, Metabolites from the biodegradation of triphenyl methane dyes by Trametes versicolor or laccase. Chemosphere 75, 1344-1349. doi:10.1016/j.chemosphere.2009.02.029

[14] Hassan, I.F. and Ai-Jawhari, H., 2015, Decolorization of methylene blue and crystal violet by some filamentous fungi. International Journal of Environmental Bioremediation \& Biodegradation 3(2), 62-65.

[15] Chen, S.H. and Ting, A.S.Y., 2015a, Biodecolorization and biodegradation potential ofrecalcitrant triphenyl methane dyes by Coriolopsis sp. isolated from compost. Journal of Environmental Management 150, 274-280. doi:10.1016/j.jenvman.2014.09.014

[16] Chen, S.H. and Ting, A.S.Y., 2015, Biosorption and biodegradation potential of triphenylmethane dyes by newly discovered Penicillium simplicissimum isolated from indoor wastewater sample. International Biodeterioration \& Biodegradation 103, 1-7. doi:10.1016/j. ibiod.2015.04.004 
[17] Li, J.F., Rupa, E.J., Hurh, J., Huo, Y., Chen, L., Hana, Y., Ahn, J.C., Park, J.K., Lee, H.A., Mathiyalagan, R., and Yang, D.-C., 2019, Cordyceps militaris fungus mediated Zinc Oxide nanoparticles for the photocatalytic degradation of Methylene blue dye. Optik 183, 691-697. doi:10.1016/j.ijleo.2019.02.081

[18] Bouras, H.D., Yeddou, A.R., Bouras, N., Hellel, D., Holtz, M.D., Sabaou, N., Chergui, A., and Nadjemi, B., 2017, Biosorption of Congo red dye by Aspergillus carbonarius M333 and Penicillium glabrum Pg1: Kinetics, equilibrium and thermodynamic studies. Journal of the Taiwan Institute of Chemical Engineers 80, 915-923. doi:10.1016/j.jtice.2017.08.002 [19] Bouras, H.D., Isik, Z., Arikan, E.B., Bouras, N., Chergui, A., Yatmaz, H.C., and Dizge, N., 2019, Photocatalytic oxidation of azo dye solutions by impregnation of $\mathrm{ZnO}$ on fungi. Biochemical Engineering Journal 146, 150-159. doi:10.1016/j.bej.2019.03.014

[20] Naskar, A. and Majumder, R., 2017, Understanding the adsorption behaviour of acid yellow 99 on Aspergillus niger biomass. Journal of Molecular Liquids 242(1), 892-899. doi:10.1016/j.molliq.2017.05.155

[21] Zhao, J., Zou, Z., Ren, R., Sui, X., Mao, Z., Xu, H., and Wang, B., 2018, Chitosan adsorbent reinforced with citric acid modified $\beta$-cyclodextrin for highly efficient removal of dyes from reactive dyeing effluents. European Polymer Journal 108, 212-218. doi:10.1016/j. eurpolymj.2018.08.044

[22] Zazycki, M.A., Godinho, M., Perondi, D., Foletto, E.L., Collazzo, G.C., and Dotto, G.L., 2018, New biochar from pecan nutshells as an alternative adsorbent for removing reactive red 141 from aqueous solutions. Journal of Cleaner Production 171, 57-65. doi:10.1016/j. jclepro.2017.10.007

[23] Fontoura, J.T., Rolim, G.S., Mella, B., Farenzena, M., and Gutterres, M., 2017, Defatted microalgal biomass as biosorbent for the removal of Acid Blue 161 dye from tannery effluent. Journal of Environmental Engineering 5, 5076-5084. 
[24] Ortiz-Monsalve, S., Dornelles, J., Poll, E., Ramirez-Castrillon, M., Valente, P., and Gutterres, M., 2017, Biodecolourisation and biodegradation of leather dyes by a native isolate of Trametes villosa. Process Safety and Environment Protection 109, 437-451. doi:10.1016/j.psep.2017.04.028

[25] Daneshvar, E., Vazirzadeh, A., Niazi, A., Sillanpää, M., and Bhatnagar, A., 2017, A comparative study of methylene blue biosorption using different modified brown, red and green macroalgae - Effect of pretreatment. Chemical Engineering Journal 307, 435-446. doi:10.1016/j.cej.2016.08.093

[26] Sharma, P., Saikia, B.K., and Das, M.R., 2014, Removal of methyl green dye molecule from aqueous system using reduced graphene oxide as an efficient adsorbent: Kinetics, isotherm and thermodynamic parameters. Colloids and Surfaces A: Physicochemical and Engineering Aspects 457, 125-133. doi:10.1016/j.colsurfa.2014.05.054

[27] Mathialagan, T. and Viraraghavan, T., 2009, Biosorption of pentachlorophenol from aqueous solutions by a fungal biomass. Bioresource Technology 100, 549-558. doi:10.1016/j. biortech.2008.06.054

[28] Üner, O., 2019, Hydrogen storage capacity and methylene blue adsorption performance of activated carbon produced from Arundo donax. Materials Chemistry Physics 237, 121858. doi:10.1016/j.matchemphys.2019.121858

[29] Shaban, M., Abukhadra, M.R., Khan, A.A.P., and Jibali, B.M., 2018, Removal of Congo red, methylene blue and Cr (VI) ions from water using natural serpentine. Journal of the Taiwan Institute of Chemical Engineers 82, 102-116. doi:10.1016/j.jtice.2017.10.023 [30] Dahri, M.K., Kooh, M.R.R., and Lim, L.B.L., 2015, Application of Casuarina equisetifolia needle for the removal of methylene blue and malachite green dyes from aqueous solution. Alexandria Engineering Journal 54, 1253-1263. doi:10.1016/j.aej.2015.07.005 [31] Deniz, F. and Kepekci, R.A., 2017, Bioremoval of Malachite green from water sample by 
forestry waste mixture as potential biosorbent. Microchemical Journal 132, 172-178. doi:10.1016/j.microc.2017.01.015

[32] Bayramoglu, G. and Arica, M.Y., 2018, Adsorption of Congo Red dye by native amine and carboxyl modified biomass of Funalia trogii: Isotherms, kinetics and thermodynamics mechanisms. Korean Journal of Chemical Engineering 35(3), 1-9. doi:10.1007/s11814-0180033-9

[33] Mahmoodi, N.M., T aghizadeh, M., and Taghizadeh, A., 2019, Activated carbon/metalorganic framework composite as a bio-based novel green adsorbent: Preparation and mathematical pollutant removal modelling. Journal of Molecular Liquids 277, 310-322. doi:10.1016/j.molliq.2018.12.050

[34] Daoud, M., Benturki, O., Kecira, Z., Girods, P., and Donnot, A., 2017, Removal of reactive dye (BEZAKTIV Red S-MAX) from aqueous solution by adsorption onto activated carbons prepared from date palm rachis and jujube stones. Journal of Molecular Liquids 243, 799-809. doi:10.1016/j.molliq.2017.08.093

[35] Langmuir, I., 1918, The adsorption of gases on plane surfaces of glass, mica and platinum. Journal of the American Chemical Society 40(9), 1361-1403. doi:10.1021/ja02242a004

[36] Dahlan, N.A., Lee, L.W., Pushpamalar, J., and Ng, S.L., 2019, Adsorption of methylene blue onto carboxymethyl sago pulp-immobilized sago waste hydrogel beads. International Journal of Environmental Science and Technology 16, 2047-2058. doi:10.1007/s13762-018$1789-5$

[37] Freundlich, H.M.F., 1906, Über die adsorption in LÖsungen. The Journal of Physical Chemistry C 57, 385-470.

[38] Tempkin, M.J. and Pyzhev, V., 1940, Kinetics of ammonia synthesis on promoted iron catalysis. Acta Physiochimica URSS 12, 327-356. 
[39] Dubinin, M.M. and Radushkevich, L.V., 1947, Proceedings of the academy of sciences of the USSR. Physical Chemistry 55, 331-333.

[40] Sharma, S., Hasan, A., Kumar, N., and Pandey, L.M., 2018, Removal of methylene blue dye from aqueous solution using immobilized Agrobacterium fabrum biomass along with iron oxide nanoparticles as biosorbent. Environmental Science and Pollution Research 25(22), 21605-21615. doi:10.1007/s11356-018-2280-z

[41] Bagheri, A.R., Ghaedi, M., Asfaram, A., Jannesar, R., and Goudarzi, A., 2016, Design andconstruction of nanoscale material for ultrasonic assisted adsorption of dyes: Application of derivative spectrophotometry and experimental design methodology. Ultrasonics Sonochemistry 35, 112-123. doi:10.1016/j.ultsonch.2016.09.008

[42] Fu, Y. and Viraraghavan, T., 2000, Removal of a dye from an aqueous solution by the fungus Aspergillus niger. Water Quality Research Journal of Canada 35, 95-111. doi:10.2166/wqrj.2000.006

[43] Acemioglu, B., Kertmen, M., Digrak, M., and Alma, M.H., 2010, Use of Aspergillus wentii for biosorption of methylene blue from aqueous solution. African Journal of Biotechnology 9(6), 874-881. doi:10.5897/AJB09.752

[44] Barka, N., Assabane, A., Aît Ichou, Y., and Nounah, A., 2006, Decantamination of textile wastewater by powdered activated carbon. Journal of Applied Sciences 6(3), 692-695. doi:10.3923/jas.2006.692.695

[45] Annadurai, G., Juang, R.S., and Lee, D.J., 2002, Use of cellulose-based wastes for adsorption of dyes from aqueous solutions. Journal of Hazardous Materials B 92, 263-274. doi:10.1016/S0304-3894(02)00017-1

[46] Dotto, G.L., Santos, J.M.N., Rodrigues, I.L., Rosa, R., Pavan, F.A., and Lima, E.C., 2015, Adsorption of methylene blue by ultrasonic surface modified chitin. Journal of Colloid and Interface Science 446, 133-140. doi:10.1016/j.jcis.2015.01.046 
[47] Ncibi, M.C., Mahjoub, B., and Seffen, M., 2007, Kinetic and equilibrium studies of methylene blue biosorption by Posidonia oceanica (L.) fibres. Journal of Hazardous Materials 139, 280-285. doi:10.1016/j.jhazmat.2006.06.029

[48] Runping, H., Yuanfeng, W., Pan, H., Jie, S., Jian, Y., and Yongsen, L., 2006, Removal of methylene blue from aqueous solution by chaff in batch mode. Journal of Hazardous Materials 137, 550-557. doi:10.1016/j.jhazmat.2006.02.029

[49] Khattri, S.D. and Singh, M.K., 1999, Colour removal from dye wastewater using sugar cane dust as an adsorbent. Adsorption Science \& Technology 17, 269-282. doi:10.1177/ 026361749901700404

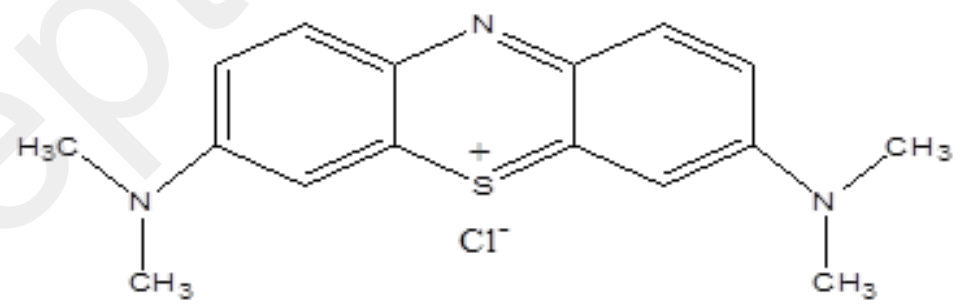

Figure 1. Chemical structure of methylene blue. 

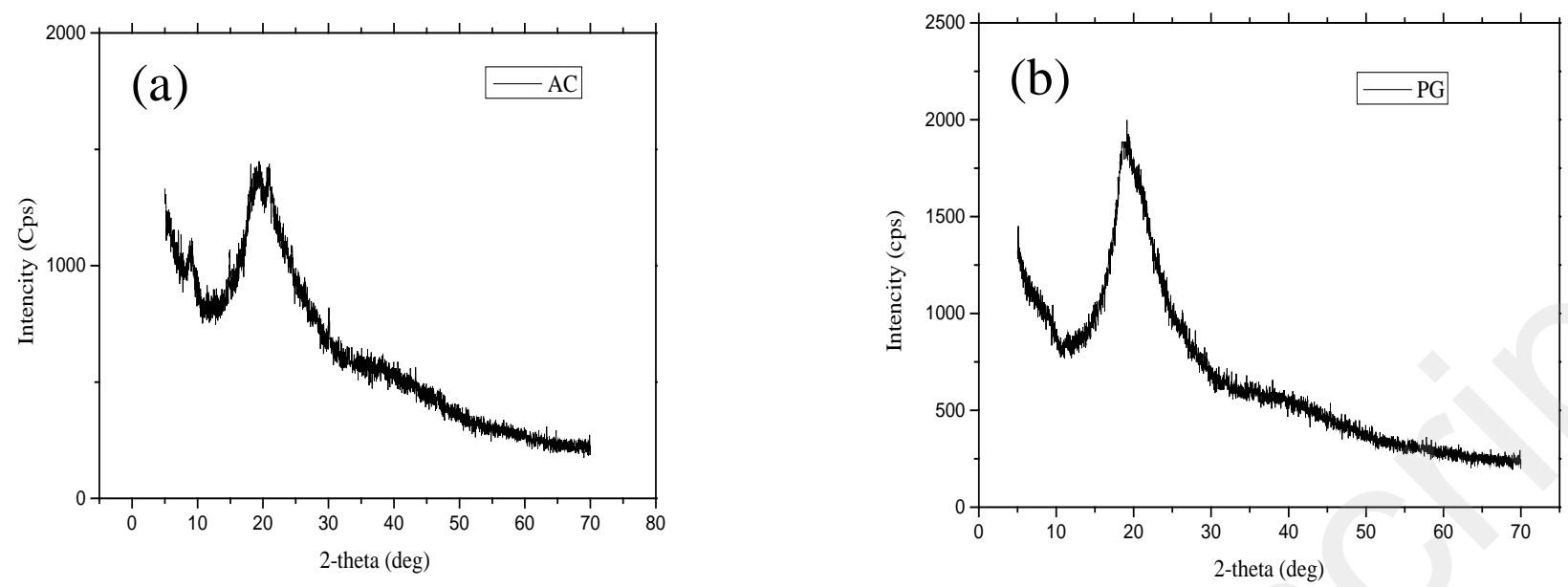

Figure 2. The X-ray diffraction (XRD) pattern of (a) Aspergillus carbonarius (AC) and (b) Penicillium glabrum (PG).
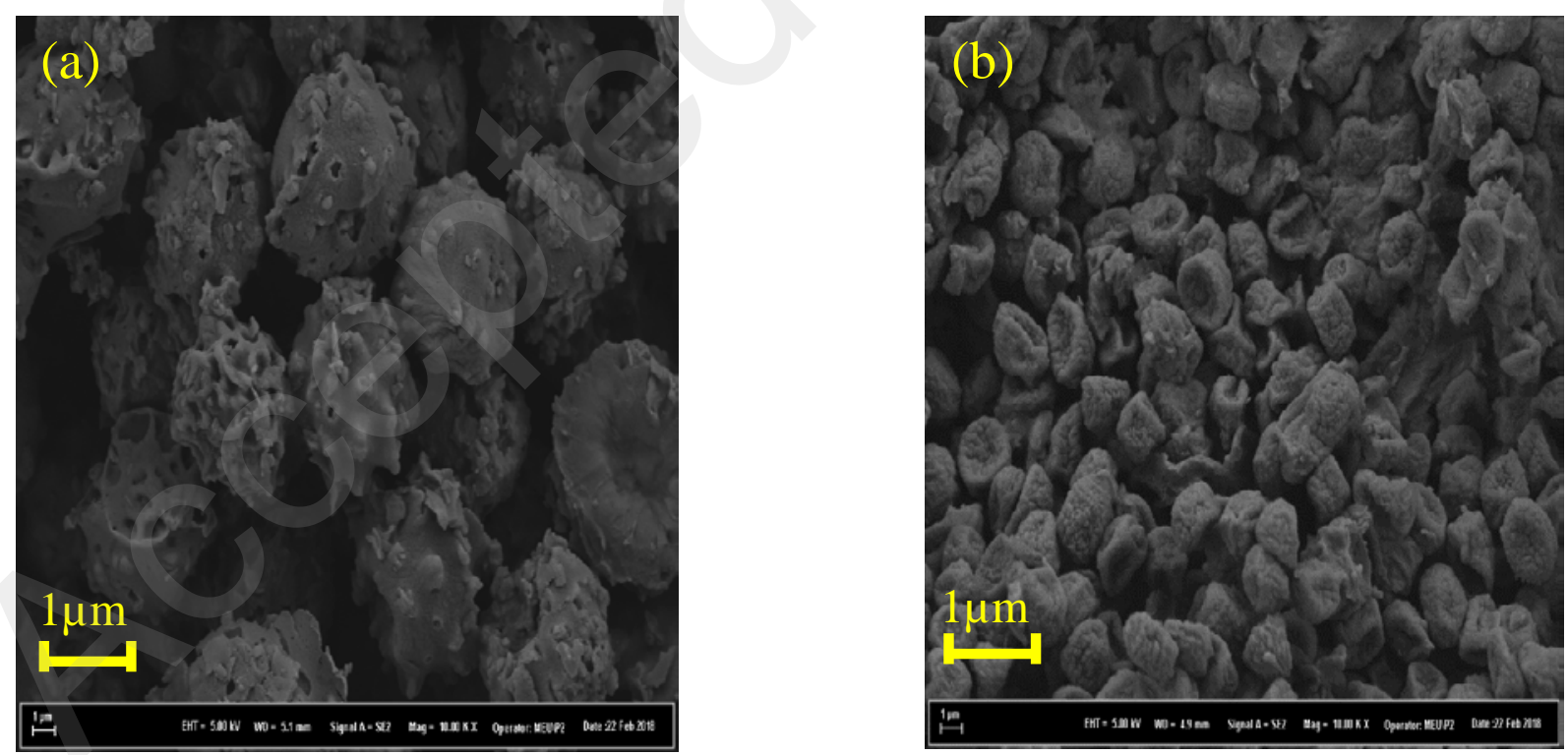

Figure 3. Scanning electron microscopy (SEM) micrographs of (a) Aspergillus carbonarius (AC) and (b) Penicillium glabrum (PG). 

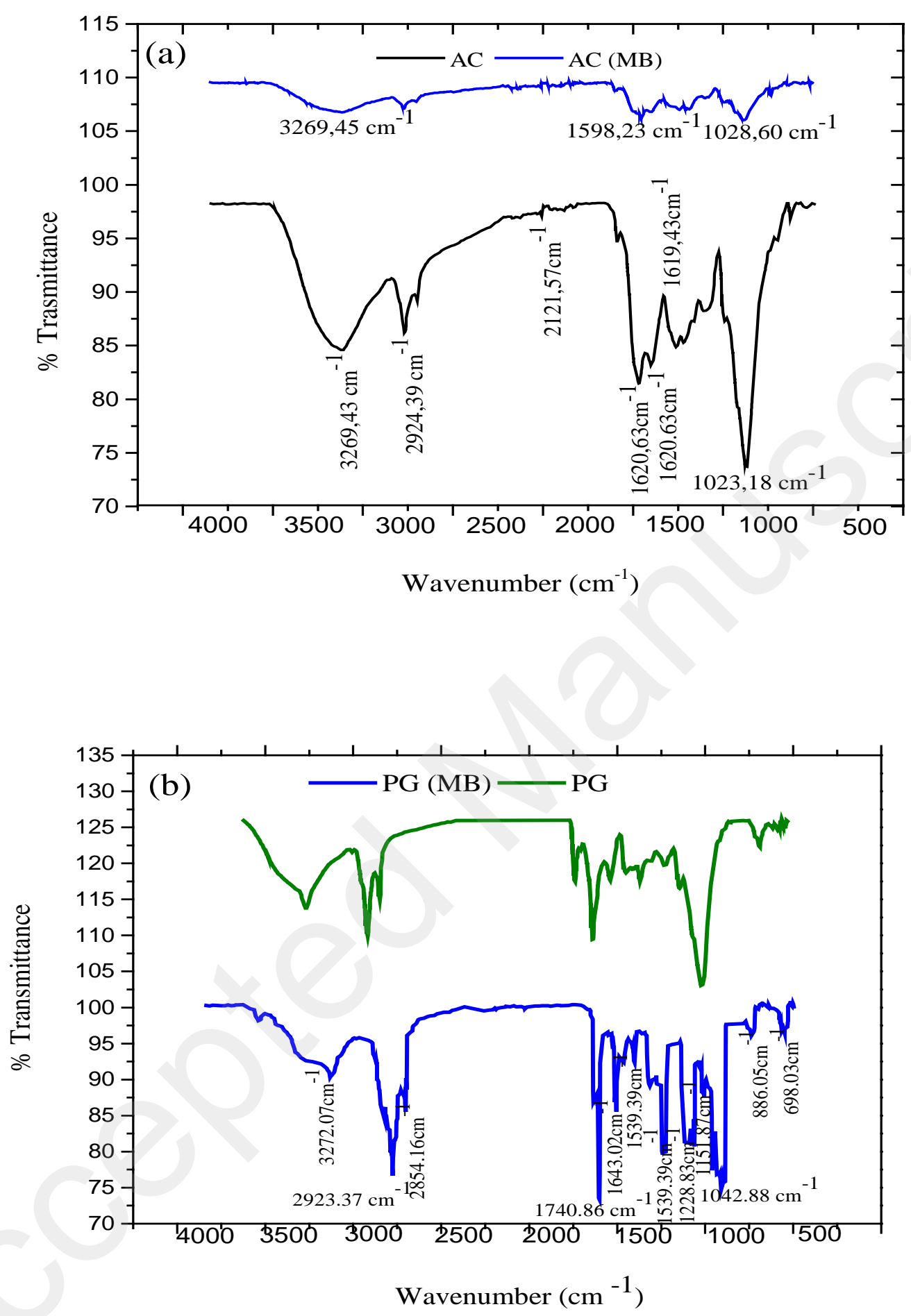

Figure 4. (a) FTIR spectra of Aspergillus carbonarius (AC) before and after biosorption of methylene blue. (b) FTIR spectra of Penicillium glabrum (PG) before and after biosorption of methylene blue. 


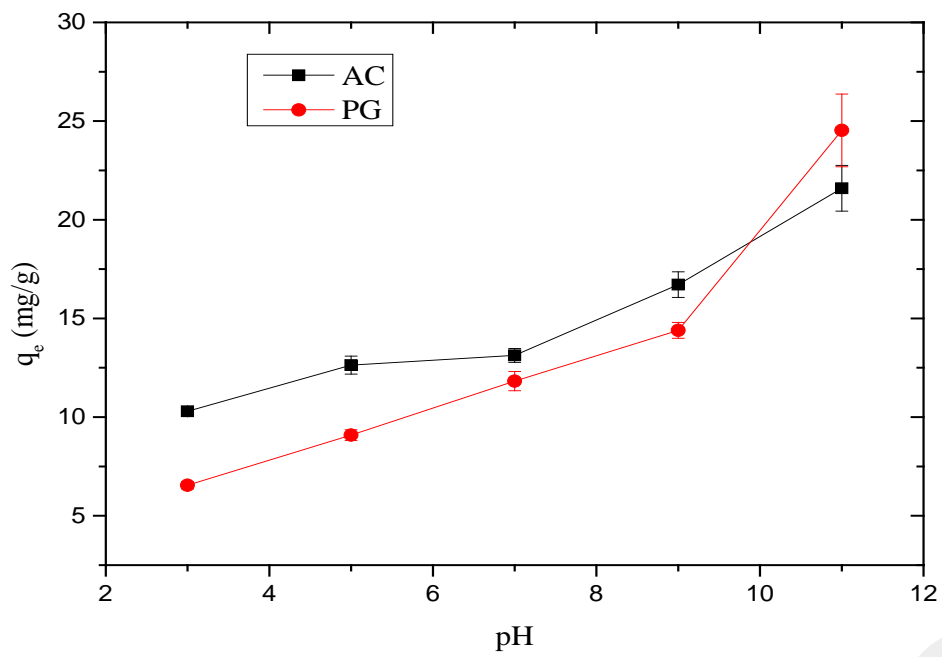

Figure 5. Effect of pH on the equilibrium uptake capacity of Aspergillus carbonarius (AC) and Penicillium glabrum (PG) for methylene blue. Conditions: $\mathrm{C}_{\mathrm{i}}=10 \mathrm{mg} / \mathrm{L}$, concentration of $0.33 \mathrm{~g} / \mathrm{L}, \mathrm{T}=303 \mathrm{~K}$.
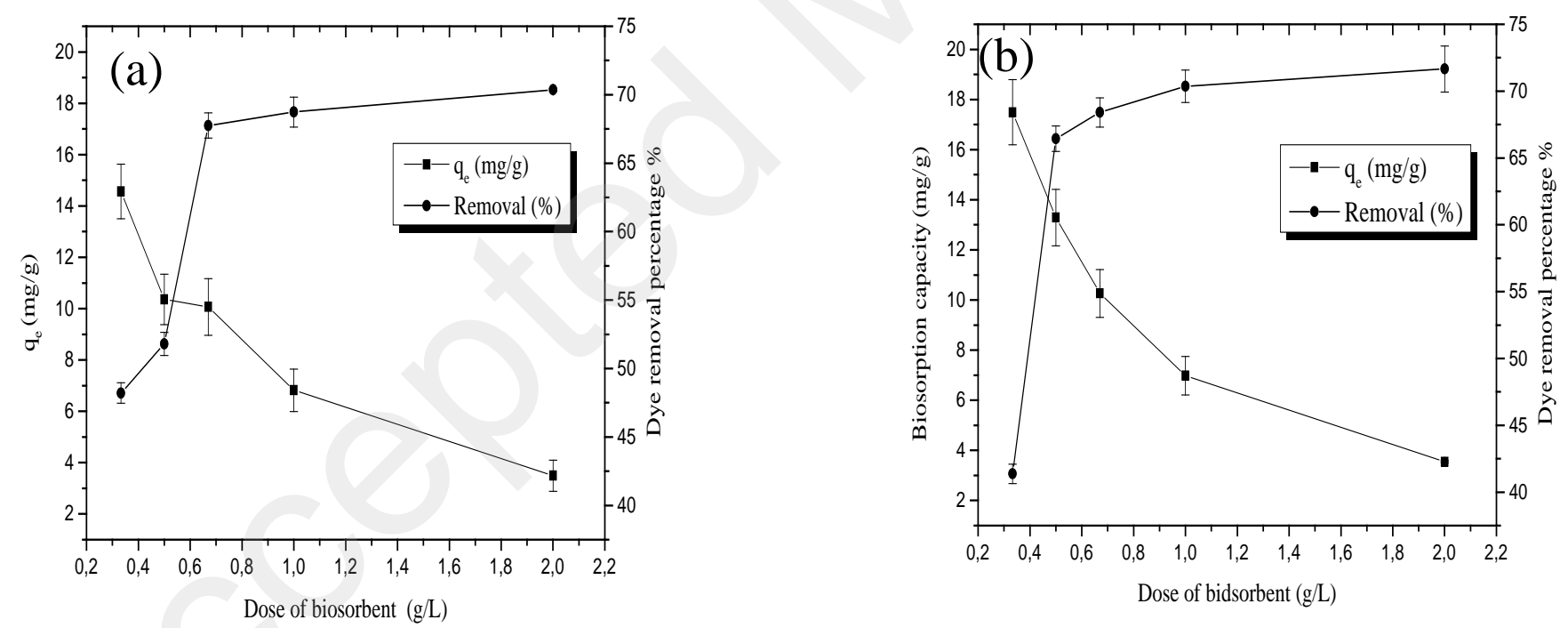

Figure 6. Effect of biosorbent concentration on the biosorption of methylene blue onto (a) Aspergillus carbonarius (AC) and (b) Penicillium glabrum (PG) [(\% removal of methylene blue and biosorption capacity (mg/g)]. Experimental conditions: initial concentrations $=10$ $\mathrm{mg} / \mathrm{L}$, biosorbent concentration $=0.33-2 \mathrm{~g}$, contact time $2 \mathrm{~h}, \mathrm{pH}$ 8.2. 


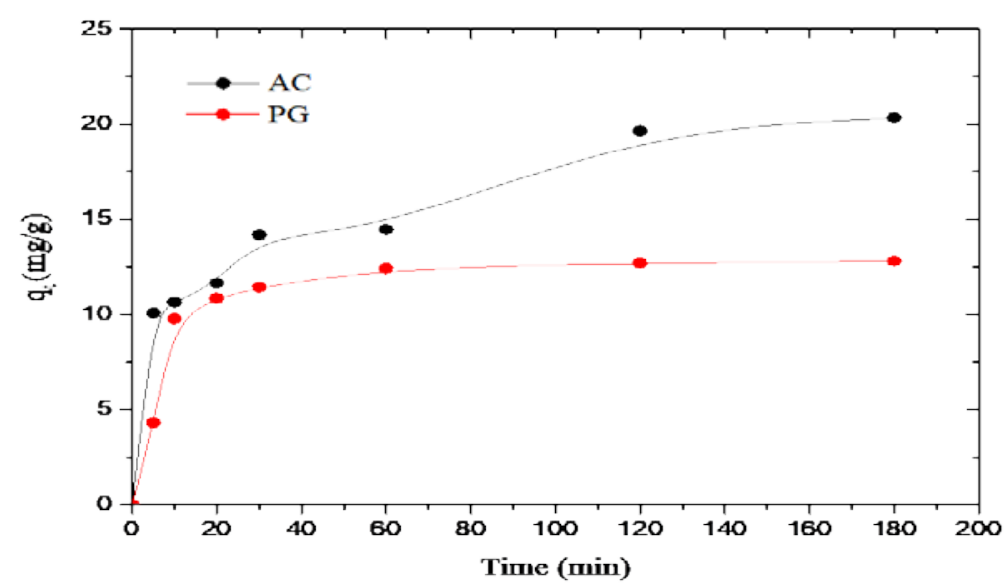

Figure. 7. Effect of contact time on the biosorption capacity of methylene blue on Aspergillus carbonarius (AC) and Penicillium glabrum (PG). Conditions: $\mathrm{Ci}=10 \mathrm{mg} / \mathrm{L}$, concentration of $0.33 \mathrm{~g} / \mathrm{L}, \mathrm{T}=303 \mathrm{~K}, \mathrm{pH} 8.2$.

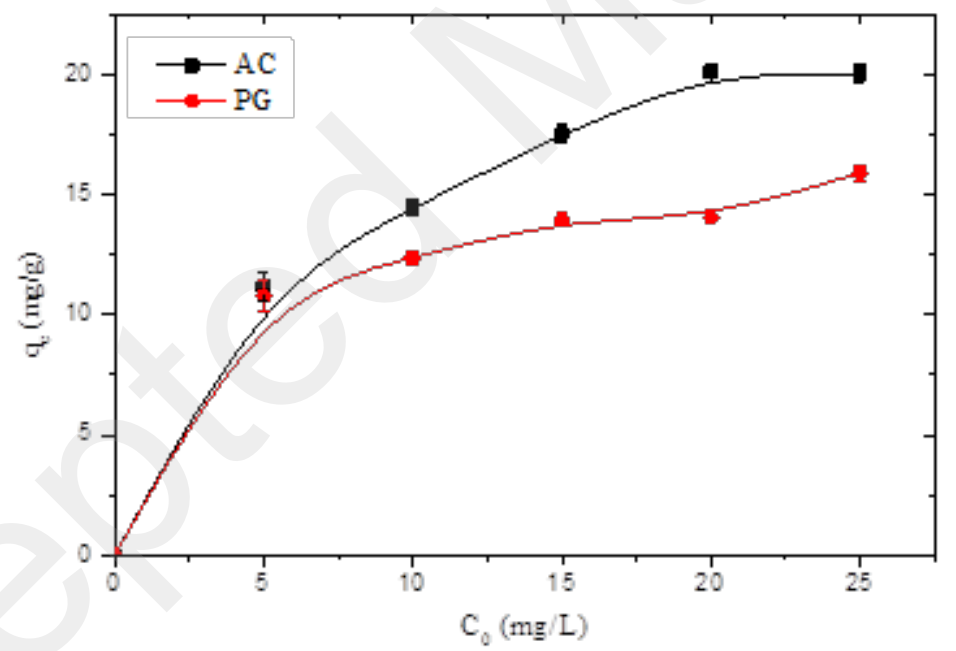

Figure 8. Effect of initial dye concentration $\left(\mathrm{C}_{0}\right)$ on biosorption capacity of Aspergillus carbonarius (AC) and Penicillium glabrum (PG) biosorbents for methylene blue (contact time: 2 h, biosorbent concentration: $0.33 \mathrm{~g} / \mathrm{L}, \mathrm{pH}$ 8.2). 


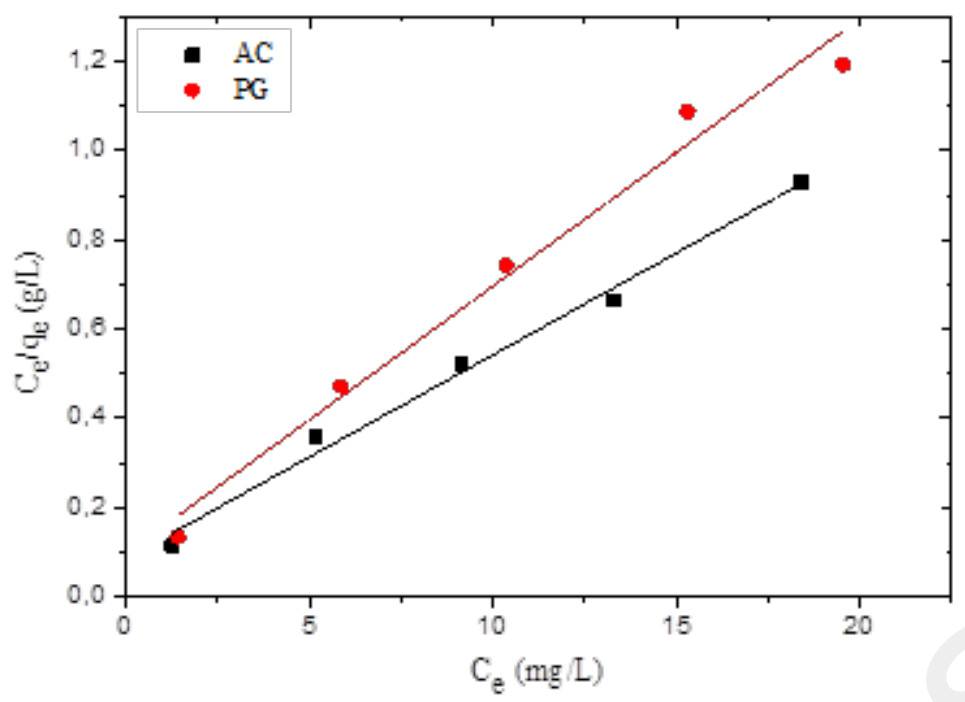

Figure 9. The Langmuir isotherm plot for the biosorption of methylene blue onto Aspergillus carbonarius (AC) and Penicillium glabrum (PG). Conditions: $\mathrm{C}_{\mathrm{i}}=10 \mathrm{mg} / \mathrm{L}$, biosorbent concentration of $0.33 \mathrm{~g} / \mathrm{L}, \mathrm{T}=303 \mathrm{~K}, \mathrm{pH} 8.2$.

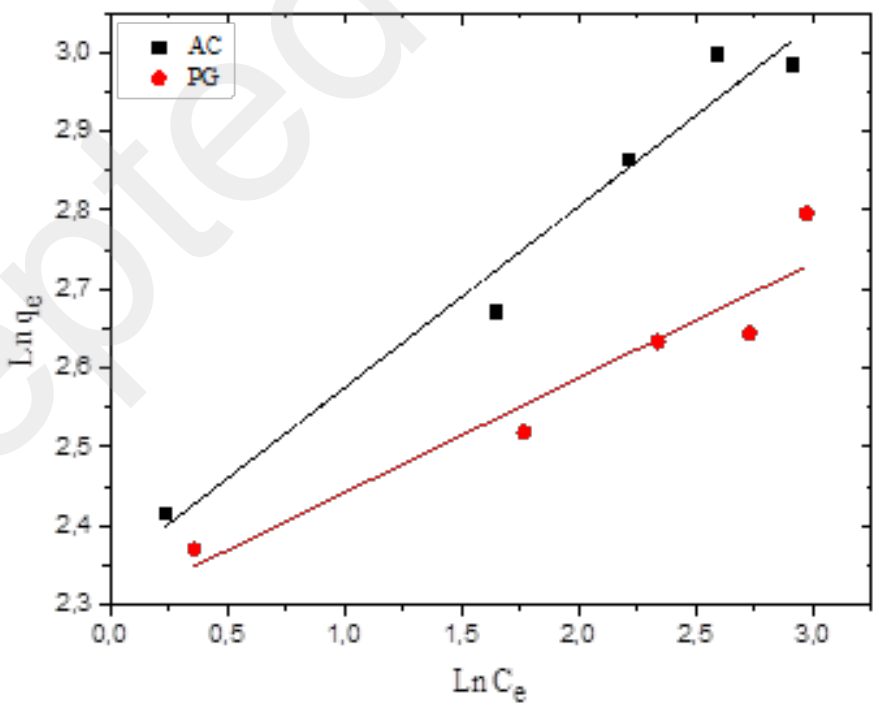

Figure 10. The Freundlich isotherm plot for the biosorption of methylene blue onto Aspergillus carbonarius (AC) and Penicillium glabrum (PG) Conditions: $\mathrm{C}_{\mathrm{i}}=10 \mathrm{mg} / \mathrm{L}$, biosorbent concentration of $0.33 \mathrm{~g} / \mathrm{L}, \mathrm{T}=303 \mathrm{~K}, \mathrm{pH} 8.2$. 
Table 1. FTIR spectral characteristics of Aspergillus carbonarius and Penicillium glabrum before and after methylene blue sorption

\begin{tabular}{|c|c|c|c|c|}
\hline \multicolumn{2}{|c|}{ Aspergillus carbonarius } & \multicolumn{2}{|c|}{ Penicillium glabrum } & \\
\hline \multicolumn{2}{|c|}{ Band position $\left(\mathrm{Cm}^{-1}\right)$} & \multicolumn{2}{|c|}{ Band position $\left(\mathrm{Cm}^{-1}\right)$} & Suggested assignments \\
\hline Before biosorption & After biosorption & Before biosorption & After biosorption & se \\
\hline 3269.43 & 3269.45 & - & - & -OH and/or-NH stretching vibration \\
\hline- & - & 3271.05 & 3272.07 & $-\mathrm{N}-\mathrm{H}$ stretching vibration \\
\hline 1620.63 & 1619.43 & - & - & $\mathrm{N}-\mathrm{H}$ deformation vibration of amide I groups \\
\hline 1023.18 & 1028.60 & - & - & $\mathrm{C}-\mathrm{N}$ stretch of amide or amine \\
\hline- & - & 2923.80 & 2923.37 & -CH stretch aliphatic \\
\hline- & - & 1742.74 & 1740.86 & $\begin{array}{l}\mathrm{C}=\mathrm{O} \text { stretching vibration of carboxylate }(- \\
\text { COO-) } /(-\mathrm{COOR}-)\end{array}$ \\
\hline- & - & 1642.76 & 1643.02 & $\begin{array}{c}\mathrm{C}=\mathrm{O} \text { stretching vibration of } \mathrm{N}-\mathrm{H} \text { deformation } \\
\text { vibration of amide I groups }\end{array}$ \\
\hline- & - & 1542.59 & 1539.39 & $\mathrm{~N}-\mathrm{H}$ deformation vibration of amide II groups \\
\hline- & - & 1027.11 & 1042.88 & $\mathrm{C}-\mathrm{O}$ stretching of carboxylic groups \\
\hline
\end{tabular}


Table 2. Kinetic parameters for the biosorption of methylene blue onto Aspergillus carbonarius and Penicillium glabrum at various initial dye concentrations.

\begin{tabular}{|c|c|c|c|c|c|c|}
\hline \multirow{2}{*}{$\begin{array}{l}\text { Samples } \\
\mathrm{C}_{0} \text { of } \mathrm{MB}(\mathrm{mg} / \mathrm{L})\end{array}$} & \multicolumn{3}{|c|}{ Aspergillus carbonarius } & \multicolumn{3}{|c|}{ Penicillium glabrum } \\
\hline & 5 & 10 & 20 & 5 & 10 & 20 \\
\hline $\mathrm{q}_{\mathrm{eq}}(\exp )(\mathrm{mg} / \mathrm{g})$ & 12.26 & 20.30 & 24.63 & 11.38 & 12.80 & 15.83 \\
\hline \multicolumn{7}{|l|}{ Pseudo-first order } \\
\hline $\mathrm{K}_{1}\left(\min ^{-1}\right)$ & $3.91 \times 10^{-2}$ & $3.93 \times 10^{-2}$ & $5.22 \times 10^{-2}$ & $4.81 \times 10^{-2}$ & $8.07 \times 10^{-2}$ & $3.01 \times 10^{-2}$ \\
\hline $\mathrm{q}_{1}(\mathrm{cal})(\mathrm{mg} / \mathrm{g})$ & 05.54 & 07.69 & 13.33 & 02.31 & 04.92 & 04.96 \\
\hline $\mathrm{R}^{2}$ & 0.821 & 0.888 & 0.925 & 0.976 & 0.927 & 0.592 \\
\hline RMSE & 0.89 & 10.77 & 17.68 & 0.064 & 4.93 & 6.93 \\
\hline \multicolumn{7}{|c|}{ Pseudo-second order } \\
\hline $\mathrm{K}_{2}$ (g/mg.min) & $1.1 \times 10^{-2}$ & $0.39 \times 10^{-2}$ & $0.90 \times 10^{-2}$ & $3.77 \times 10^{-2}$ & $1.22 \times 10^{-2}$ & $1.58 \times 10^{-2}$ \\
\hline $\mathrm{q}_{2}(\mathrm{cal})(\mathrm{mg} / \mathrm{g})$ & 12.05 & 20.58 & 24.04 & 11.34 & 13.46 & 15.04 \\
\hline $\mathrm{R}^{2}$ & 0.996 & 0.971 & 0.991 & 0.999 & 0.997 & 0.999 \\
\hline RMSE & 1.11 & 2.02 & 1.05 & 0.40 & 1.37 & 1.10 \\
\hline \multirow{2}{*}{\multicolumn{7}{|c|}{$\begin{array}{l}\text { Intraparticle diffusion } \\
\text { model }\end{array}$}} \\
\hline & & & & & & \\
\hline $\mathrm{K}_{\mathrm{id}}\left(\mathrm{mg} / \mathrm{g} \min ^{1 / 2}\right)$ & 0.64 & 1.07 & 0.58 & 0.25 & 0.74 & 0.74 \\
\hline C & 5.14 & 7.35 & 16.78 & 8.68 & 6.06 & 7.90 \\
\hline $\mathrm{R}^{2}$ & 0.867 & 0.952 & 0.887 & 0.904 & 0.584 & 0.578 \\
\hline RMSE & 0.82 & 0.75 & 0.56 & 0.09 & 4.99 & 5.16 \\
\hline \multicolumn{7}{|l|}{ Elovich } \\
\hline$\alpha(\mathrm{mg} / \mathrm{g} \cdot \mathrm{min})$ & 2.86 & 4.35 & 15.21 & 7.78 & 2.72 & 4.46 \\
\hline$\beta(\mathrm{g} / \mathrm{mg})$ & 1.85 & 2.84 & 1.52 & 0.72 & 2.35 & 2.38 \\
\hline $\mathrm{R}^{2}$ & 0.930 & 0.871 & 0.788 & 0.986 & 0.774 & 0.785 \\
\hline RMSE & 6.67 & 17.86 & 5.65 & 0.012 & 2.71 & 2.63 \\
\hline
\end{tabular}


Table 3.

Isotherm parameters for the biosorption of methylene blue from aqueous solutions onto Aspergillus carbonarius and Penicillium glabrum.

\begin{tabular}{|c|c|c|}
\hline Samples & Aspergillus carbonarius & Penicillium glabrum \\
\hline \multicolumn{3}{|l|}{ Langmuir } \\
\hline $\mathrm{q}_{\mathrm{m}}(\mathrm{mg} / \mathrm{g})$ & 21.88 & 16.67 \\
\hline b (L/mg) & 0.538 & 0.621 \\
\hline $\mathrm{R}_{\mathrm{L}}$ & 0.157 & 0.139 \\
\hline $\mathrm{R}^{2}$ & 0.991 & 0.984 \\
\hline RMSE & 15.72 & 03.60 \\
\hline \multicolumn{3}{|l|}{ Freundlich } \\
\hline $\mathrm{K}_{\mathrm{F}}(\mathrm{mg} / \mathrm{g})(\mathrm{mg} / \mathrm{L})^{1 / \mathrm{n}}$ & 10.43 & 9.94 \\
\hline $\mathrm{n}_{\mathrm{F}}$ & 4.34 & 6.87 \\
\hline $\mathrm{R}^{2}$ & 0.927 & 0.915 \\
\hline RMSE & 0.74 & 0.62 \\
\hline \multicolumn{3}{|l|}{ Temkin } \\
\hline $\mathrm{K}_{\mathrm{T}}(\mathrm{L} / \mathrm{g})$ & 0.018 & 0.163 \\
\hline $\mathrm{b}_{\mathrm{T}}(\mathrm{kJ} / \mathrm{mole})$ & 0.722 & 1.331 \\
\hline $\mathrm{R}^{2}$ & 0.949 & 0.873 \\
\hline RMSE & 0.96 & 0.75 \\
\hline \multicolumn{3}{|c|}{ Dubinin-Radushkevich } \\
\hline $\mathrm{q}_{\mathrm{DR}}(\mathrm{mg} / \mathrm{g})$ & 18 & 14 \\
\hline $\mathrm{K}_{\mathrm{DR}}\left(\mathrm{mole}^{2} / \mathrm{kJ}^{2}\right)$ & 2E-07 & 2E-07 \\
\hline $\mathrm{E}(\mathrm{kJ} / \mathrm{mole})$ & 1.581 & 1.581 \\
\hline $\mathrm{R}^{2}$ & 0.781 & 0.673 \\
\hline RMSE & 5.46 & 2.36 \\
\hline
\end{tabular}


Table 4. Comparison of biosorption capacities of various biosorbents for removal of methylene blue.

\begin{tabular}{llll}
\hline Biosorbents & $\mathrm{pH}$ & $\mathrm{q}_{\mathrm{m}}(\mathrm{mg} / \mathrm{g})$ & References \\
\hline Aspergillus fumigatus & 7.0 & 125 & {$[5]$} \\
Aspergillus wentii & 6.33 & 3.30 & {$[42]$} \\
Aspergillus niger & 6.0 & 18.54 & {$[43]$} \\
Activated carbon & 10 & 294.12 & {$[44]$} \\
Orange peel & 7.2 & 13.90 & {$[45]$} \\
Carica papaya wood & 7.35 & 32.25 & {$[2]$} \\
Casuarina seed-biocha & 7.93 & 4.69 & {$[1]$} \\
USM-chitin & 10 & 26.69 & {$[46]$} \\
Posidonia oceanica & 6.0 & 5.56 & {$[47]$} \\
Cereal chaff & 7.0 & 20.30 & {$[48]$} \\
Sugarcane dust & 7.5 & 04.88 & {$[49]$} \\
Aspergillus carbonarius & 8.2 & 21.88 & Present work \\
Penicillium glabrum & 8.2 & 16.67 & Present work \\
\hline
\end{tabular}

